\title{
Amyloid-like Behavior in Abiotic, Amphiphilic Foldamers
}

\author{
Valerie J. Bradford and Brent L. Iverson* \\ Contribution from the Department of Chemistry and Biochemistry, The University of Texas at Austin, \\ Texas 78712 \\ E-mail: biverson@mail.utexas.edu
}

General Methods and Materials: Trifluoroacetic acid (TFA), piperidine, and $N$-methyl morpholine (NMM) were purchased from Sigma-Aldrich. All amino acid derivatives, PyBop, HOBt and Fmoc-GlyWang resin were purchased from Novabiochem.

Monomer Synthesis: The Fmoc-Asp(tBu)-NDI monomer unit and Boc-DAN-OH was synthesized according to previously published methods. ${ }^{1}$ The Fmoc-R-DAN monomer units, where $\mathrm{R}$ is leucine, norleucine, isoleucine, or valine, were synthesized as described below.

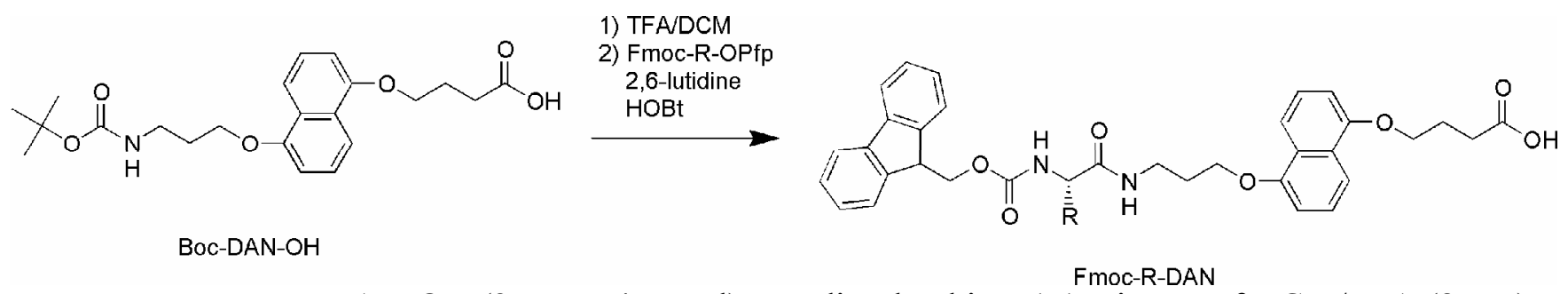

Fmoc-Ile-Dan: Boc-DAN-OH (2.5 g, $5.4 \mathrm{mmol})$ was dissolved in a 1:1 mixture of DCM/TFA $(8 \mathrm{~mL})$ and stirred for 30 minutes at room temperature. The mixture was concentrated via rotary evaporation and azeotropically dried from n-heptane. The solid was dissolved in dry DMF (61 mL). To the solution, 2,6-lutidine (2.54 mL, 4 eq.) was added, followed by N-hydroxybenzotriazole (HOBt, 0.83 g, 1 eq.) and the pentafluorophenol ester of Fmoc-protected isoleucine (Fmoc-Ile-OPfp, 2.69 g, 0.95 eq.). After stirring overnight at room temperature under a nitrogen atmosphere, the reaction mixture was partitioned 
between ethyl acetate and $0.2 \mathrm{M}$ citric acid buffer, $\mathrm{pH}=4.5$. The organic layer was extracted with buffer $(3 x)$, water $(3 x)$, and brine $(1 x)$, then dried over sodium sulfate. The solvent was evaporated under reduced pressure. The residue was precipitated with pentane and filtered. The filtrate was triturated with cold diethyl ether to produce a tan solid (3.26 g) in 94\% yields. ${ }^{1} \mathrm{H}$ NMR $\delta(400 \mathrm{MHz}, \mathrm{DMSO}): 8.11$ (t, 1H), $7.86(\mathrm{~d}, 2 \mathrm{H}), 7.72(\mathrm{~m}, 4 \mathrm{H}), 7.37(\mathrm{~m}, 7 \mathrm{H}), 6.93(\mathrm{~d}, 1 \mathrm{H}), 6.90(\mathrm{~d}, 1 \mathrm{H}), 4.25(\mathrm{~m}, 4 \mathrm{H}), 4.25(\mathrm{t}, 4 \mathrm{H})$, $3.81(\mathrm{t}, 1 \mathrm{H}), 3.33(\mathrm{~m}, 3 \mathrm{H}), 2.09(\mathrm{~m}, 2 \mathrm{H}), 2.04(\mathrm{~m}, 2 \mathrm{H}), 1.74(\mathrm{~m}, 1 \mathrm{H}), 1.44(\mathrm{~m}, 1 \mathrm{H}), 1.12(\mathrm{~m}, 1 \mathrm{H}), 0.81$ (m, 6H). ${ }^{13} \mathrm{C}$ NMR: $174.91,172.07,156.74,154.58,154.53,144.50,144.46,141.41,128.34,127.73$, $126.67,126.10,120.80,114.30,114.26,106.36,67.63,66.30,65.98,47.39,36.83,36.15,31.12,29.52$, 25.21, 25.00, 16.07, 11.48. HRMS (CI): calculated for $\mathrm{C}_{38} \mathrm{H}_{42} \mathrm{~N}_{2} \mathrm{O}_{7}(\mathrm{M}+\mathrm{H})^{+1}: \mathrm{m} / \mathrm{z} 639.3070$, found 639.3064 .

Fmoc-Leu-DAN: Synthesized according to the above procedure. ${ }^{1} \mathrm{H}$ NMR $\delta(400 \mathrm{MHz}, \mathrm{DMSO})$ : $8.06(\mathrm{t}, 1 \mathrm{H}), 7.86(\mathrm{~d}, 2 \mathrm{H}), 7.71(\mathrm{~m}, 4 \mathrm{H}), 7.48(\mathrm{~d}, 1 \mathrm{H}), 7.33(\mathrm{~m}, 6 \mathrm{H}), 6.93(\mathrm{~d}, 1 \mathrm{H}), 6.90(\mathrm{~d}, 1 \mathrm{H}), 4.25(\mathrm{~m}$, 4H), $4.11(\mathrm{~m}, 4 \mathrm{H}), 4.01(\mathrm{~m}, 1 \mathrm{H}), 3.35(\mathrm{~m}, 2 \mathrm{H}), 2.07(\mathrm{~m}, 2 \mathrm{H}), 1.97(\mathrm{~m}, 2 \mathrm{H}), 1.50(\mathrm{~m}, 4 \mathrm{H}), 0.84(\mathrm{~m}, 6 \mathrm{H})$. ${ }^{13} \mathrm{C}$ NMR: $174.91,173.07,156.60,154.57,154.54,144.58,144.43,141.40,128.30,127.70,126.67$, $126.64,126.07,126.01,125.99,120.77,120.75,114.32,114.26,106.34,67.61,66.19,65.99,53.85$, 47.38, 41.53, 36.29, 31.14, 25.01, 24.91, 23.62, 22.21. HRMS (CI): calculated for $\mathrm{C}_{38} \mathrm{H}_{42} \mathrm{~N}_{2} \mathrm{O}_{7}$ $(\mathrm{M}+\mathrm{H})^{+1}: \mathrm{m} / \mathrm{z} 639.3070$, found 639.3076 .

Fmoc-Nle-DAN: Synthesized according to the above procedure. ${ }^{1} \mathrm{H}$ NMR $\delta$ (400 MHz, DMSO): 8.05 $(\mathrm{t}, 1 \mathrm{H}), 7.86(\mathrm{~d}, 2 \mathrm{H}), 7.70(\mathrm{~m}, 3 \mathrm{H}), 7.46(\mathrm{~d}, 1 \mathrm{H}), 7.37(\mathrm{~m}, 5 \mathrm{H}), 6.90(\mathrm{~m}, 2 \mathrm{H}), 4.26(\mathrm{~m}, 3 \mathrm{H}), 4.12(\mathrm{~m}$, $3 \mathrm{H}), 3.91(\mathrm{q}, 1 \mathrm{H}), 3.33(\mathrm{~m}, 2 \mathrm{H}), 2.48(\mathrm{~m}, 2 \mathrm{H}), 2.07(\mathrm{~m}, 2 \mathrm{H}), 1.98(\mathrm{~m}, 2 \mathrm{H}), 1.59(\mathrm{bm}, 1 \mathrm{H}), 1.50$ (bm, 1H), $1.24(\mathrm{~m}, 4 \mathrm{H}), 0.81(\mathrm{~m}, 3 \mathrm{H}) .{ }^{13} \mathrm{C}$ NMR: 174.19, 172.03, 155.91, 153.88, 153.84, 143.87, 143.74, $140.68,127.57,126.98,125.98,125.95,120.02,113.63,113.57,105.60,66.89,65.55,65.29,64.88$, 54.74, 46.67, 35.58, 31.70, 30.48, 28.88, 27.66, 24.32, 21.81, 13.82. HRMS (CI): calculated for $\mathrm{C}_{38} \mathrm{H}_{42} \mathrm{~N}_{2} \mathrm{O}_{7}(\mathrm{M}+\mathrm{H})^{+1}: \mathrm{m} / \mathrm{z} 639.3070$, found 639.3074 .

Fmoc-Val-DAN: Synthesized according to the above procedure. ${ }^{1} \mathrm{H}$ NMR $\delta$ (400 MHz, DMSO): 8.10 (t, 1H), $7.86(\mathrm{~d}, 2 \mathrm{H}), 7.71(\mathrm{~m}, 4 \mathrm{H}), 7.34(\mathrm{~m}, 7 \mathrm{H}), 6.93(\mathrm{~d}, 1 \mathrm{H}), 6.90(\mathrm{~d}, 1 \mathrm{H}), 4.22(\mathrm{~m}, 4 \mathrm{H}), 4.13(\mathrm{t}, 4 \mathrm{H})$, 
$3.80(\mathrm{t}, 1 \mathrm{H}), 3.34(\mathrm{~m}, 3 \mathrm{H}), 2.05(\mathrm{~m}, 2 \mathrm{H}), 1.97(\mathrm{~m}, 3 \mathrm{H}), 0.85(\mathrm{~m}, 6 \mathrm{H}) .{ }^{13} \mathrm{C}$ NMR: HRMS (CI): calculated for $\mathrm{C}_{37} \mathrm{H}_{41} \mathrm{~N}_{2} \mathrm{O}_{7}(\mathrm{M}+\mathrm{H})^{+1}$ : m/z 625.2914, found 625.2915.

Solid Phase Synthesis: All hexamers were synthesized using standard Fmoc solid phase peptide synthesis methods starting with Fmoc-Glycine substituted Wang resin and utilizing Fmoc-Asp(tBu)-NDI and Fmoc-R-DAN monomers with PyBop/HOBt/NMM as coupling reagents. The resin was capped with acetic anhydride after each coupling step. The product was cleaved using TFA/phenol as the cleavage cocktail. Crude product was purified via RP-HPLC (semi-preparative Vydac C18 peptide/protein column) using a linear gradient from $24 \% \mathrm{~B}$ to $46 \% \mathrm{~B}$ over $60 \mathrm{~min}$, where solvent $\mathrm{A}$ is $10 \mathrm{mM}$ ammonium acetate buffer and solvent B is acetonitrile. After lyophilization, peptide was desalted using a Waters SepPak C18 cartridge and eluted with 1:1 $\mathrm{H}_{2} \mathrm{O}$ /acetonitrile.

Compound 1: Ac(Leu-DAN-Asp-NDI) ${ }_{3} \mathrm{Gly}-\mathrm{OH}(\mathrm{ESI})$ calculated for $\mathrm{C}_{142} \mathrm{H}_{149} \mathrm{~N}_{19} \mathrm{O}_{39}(\mathrm{M}-2 \mathrm{H})^{-2}$ : $\mathrm{m} / \mathrm{z}$ 1372.014, found 1372.008 .

Compound 2: Ac(Nle-DAN-Asp-NDI) ${ }_{3} \mathrm{Gly}-\mathrm{OH}(\mathrm{ESI})$ calculated for $\mathrm{C}_{142} \mathrm{H}_{149} \mathrm{~N}_{19} \mathrm{O}_{39}(\mathrm{M}-2 \mathrm{H})^{-2}: \mathrm{m} / \mathrm{z}$ 1372.014, found 1372.017 .

Compound 3: Ac(Ile-DAN-Asp-NDI) ${ }_{3} \mathrm{Gly}-\mathrm{OH}$ (ESI) calculated for $\mathrm{C}_{142} \mathrm{H}_{148} \mathrm{~N}_{19} \mathrm{O}_{39}(\mathrm{M}-3 \mathrm{H})^{-3}$ : $\mathrm{m} / \mathrm{z}$ 914.340, found 914.338.

Compound 4: Ac(Val-DAN-Asp-NDI) ${ }_{3} \mathrm{Gly}-\mathrm{OH}(\mathrm{ESI})$ calculated for $\mathrm{C}_{139} \mathrm{H}_{143} \mathrm{~N}_{19} \mathrm{O}_{39}(\mathrm{M}-2 \mathrm{H})^{-2}: \mathrm{m} / \mathrm{z}$ 1350.990, found 1350.991.

\section{Experimental Methods}

HPLC. HPLC was performed on a Waters HPLC system equipped with a photodiode detector and Vydac C18 peptide/protein analytical reversed phase column with a gradient of $22 \%$ B to $44 \%$ B over 60 minutes, where solvent $\mathrm{A}$ is $10 \mathrm{mM}$ ammonium acetate buffer and solvent $\mathrm{B}$ is acetonitrile. All chromatograms were monitored at $384 \mathrm{~nm}$.

UV Spectroscopy. Ultraviolet spectra (UV) were recorded on a Perkin-Elmer Lambda 35 spectrophotometer for the series of aedamers 1-4 $(15 \mu \mathrm{M})$ in $50 \mathrm{mM}$ Phosphate buffer at $\mathrm{pH}=7.0$ in a 1 cm cuvette. Cetyl trimethylammonium bromide (CTAB) was added as a solid to achieve a $2 \%(\mathrm{w} / \mathrm{v})$ 
solution and the UV spectrum was recorded. Observed percent hypochromism is reported as [( $\mathrm{Abs}_{382}$ with CTAB - $\mathrm{Abs}_{386}$ without CTAB)/ $\mathrm{Abs}_{382}$ with CTAB] x 100.

Light Scattering. Light scattering was performed on a Wyatt Technologies DynaPro MS dynamic light scattering instrument. Measurements were obtained using filtered, $2.5 \mathrm{mM}$ samples in $50 \mathrm{mM}$ sodium phosphate buffer at $\mathrm{pH}=7.0$ and $100 \mathrm{mM}$ sodium chloride in a microcuvette. Data was analyzed assuming a globular protein structure with cumulants analysis utilizing software provided by the manufacturer.

Visible Spectroscopy. Visible spectra were recorded on a Perkin-Elmer Lambda 35 spectrophotometer. Solutions of compounds 1-4 at $2.5 \mathrm{mM}$ concentration were dissolved in $50 \mathrm{mM}$ sodium phosphate buffer at $\mathrm{pH} 7.0$ with $100 \mathrm{mM} \mathrm{NaCl}$, filtered using a $0.45 \mu \mathrm{m}$ nylon filter, and placed in a $1 \mathrm{~mm}$ pathlength cell. An initial spectrum was recorded and the samples were heated in an $80^{\circ} \mathrm{C}$ water bath for 1.5 hours and cooled to room temperature before a final spectrum was taken.

Rheology. Dynamic frequency, time, temperature and strain sweep experiments were performed on a Anton Paar Physica MCR 300 rheometer equipped with a Peltier temperature controller and a $25 \mathrm{~mm}$ diameter parallel plate. All experiments were performed at $25^{\circ} \mathrm{C}$ except the temperature sweep experiment was performed during a ramp of $25^{\circ} \mathrm{C}$ to $80^{\circ} \mathrm{C}$. Gels were formed in the rheometer by placing a sample of $4 \mathrm{mM}$ preformed gel in the rheometer, lowering the top plate, and using capillary action to fill the $1 \mathrm{~mm}$ gap with a $4 \mathrm{mM}$ solution of compound. The plate was covered with silicon oil and the rheometer was heated to $80^{\circ} \mathrm{C}$ for 1 hour. Gel strength was characterized by the storage, G', and loss, G”, moduli via frequency sweep experiments at a constant strain of $0.5 \%$. Shear thinning studies were performed by measuring the viscosity while changing the shear rate from 0.1 to $100 \mathrm{~s}^{-1}$. Recovery of the elastic properties of the gel formed from 1 was measured by applying a $1000 \%$ strain for $180 \mathrm{~s}$ at a frequency of $6 \mathrm{~Hz}$ then reducing the strain to $0.5 \%$ at the same frequency and monitoring the storage and loss moduli for 15 minutes.

Circular Dichroism. Circular dichroic experiments were performed on a Jasco J-815 circular spectropolarimeter and collected at $25^{\circ} \mathrm{C}$ in a $1 \mathrm{~mm}$ quartz cell. Samples were measured at $0.2 \mathrm{mM}$ 
concentration in $50 \mathrm{mM}$ sodium phosphate buffer at pH 7.0 with $100 \mathrm{mM} \mathrm{NaCl}$ added. After an initial spectrum was recorded, the samples were heated to $80^{\circ} \mathrm{C}$ for 1 hour using the Peltier temperature controller. The samples were then cooled to $25^{\circ} \mathrm{C}$ before the final spectrum was recorded.

SEM. Hydrogels were applied to copper grids by dipping the grids in preformed gel samples. The coated grids were dipped in deionized water to desalt the gel and frozen by submerging in liquid nitrogen. The grids were lyophilized to dryness and coated with $8 \mathrm{~nm} \mathrm{Pt/Pd}$. Images were obtained with a Zeiss Supra 40 VP scanning electron microscope at $5 \mathrm{kV}$ using either an SE2 or in-lens camera. 
Compound 1

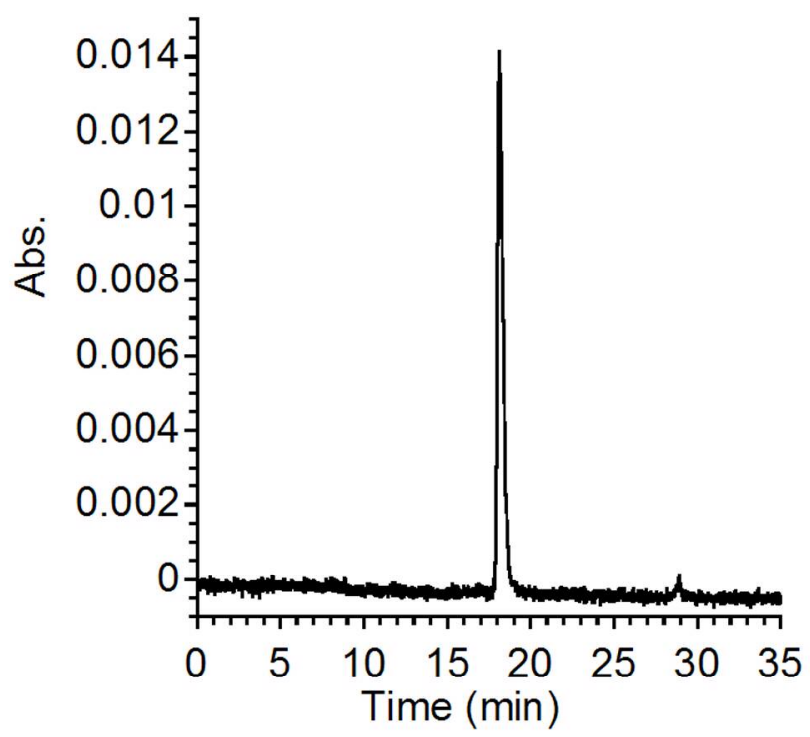

Compound 3

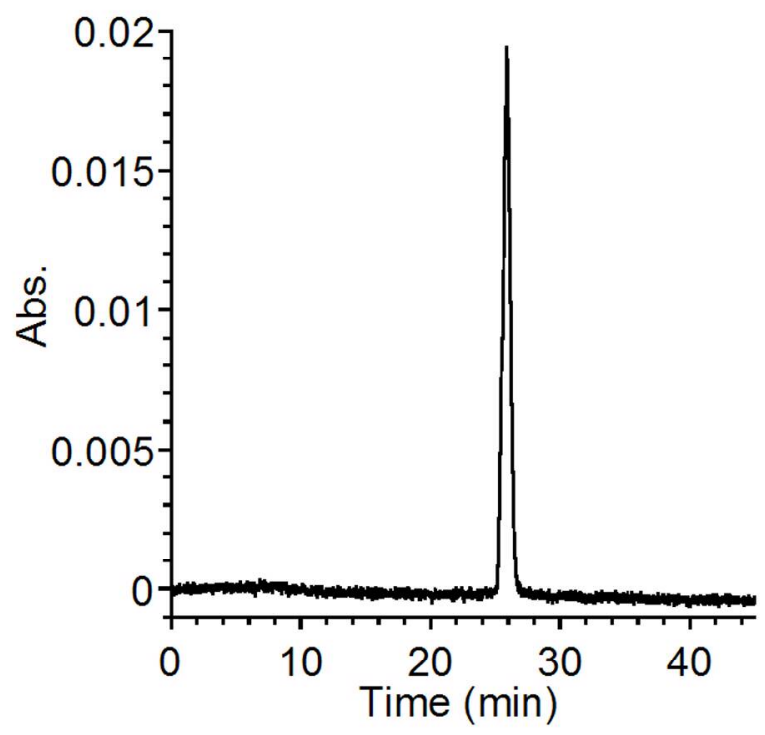

Compound 2

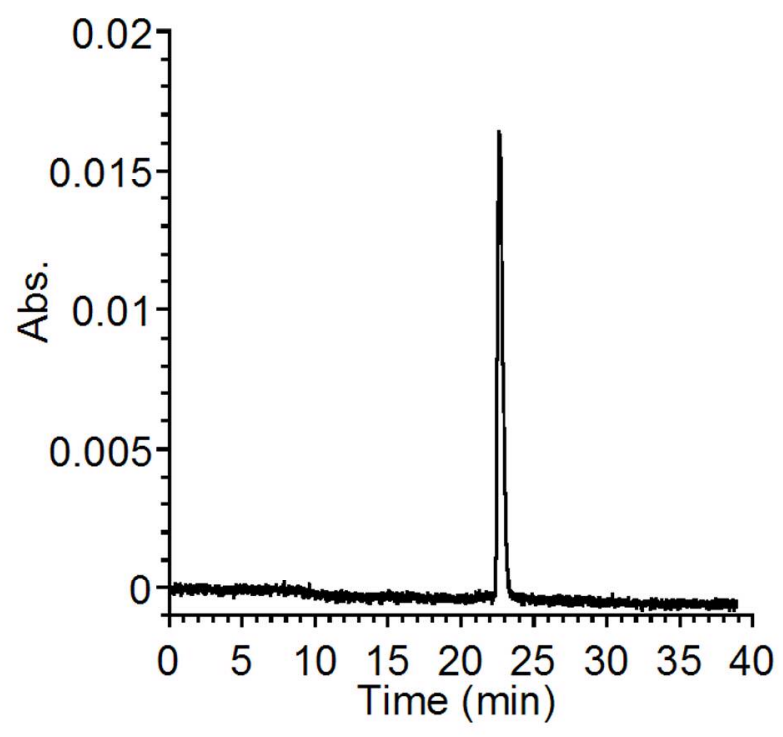

Compound 4

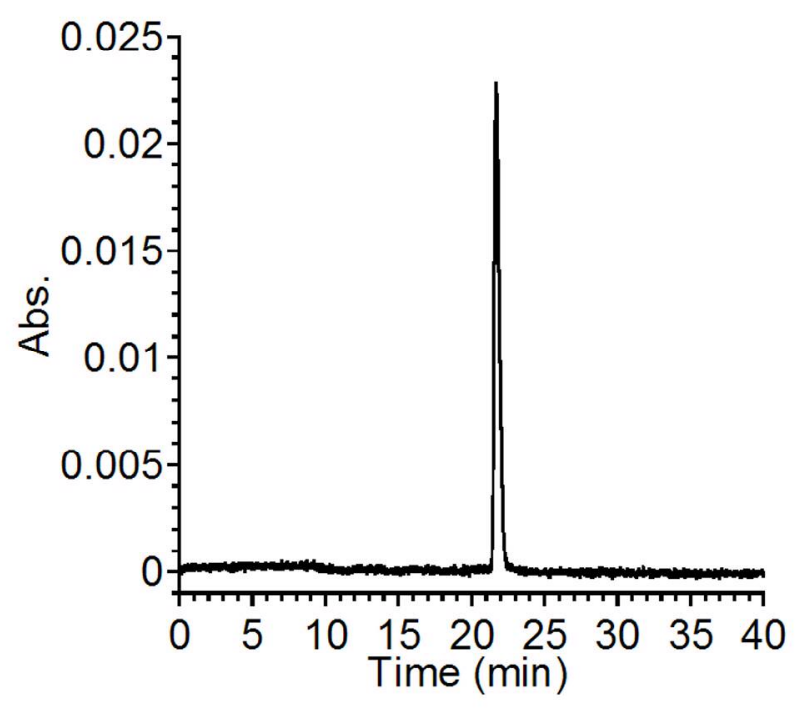

Figure S1. Analytical HPLC chromatograms of purified compounds 1-4. 
(a)

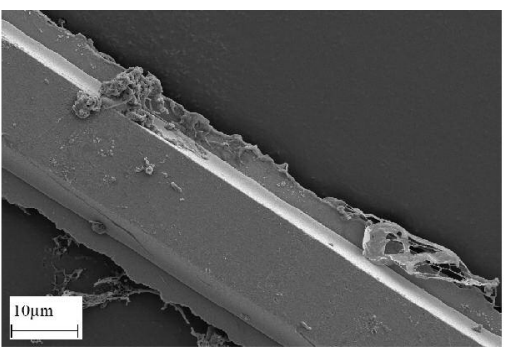

(b)

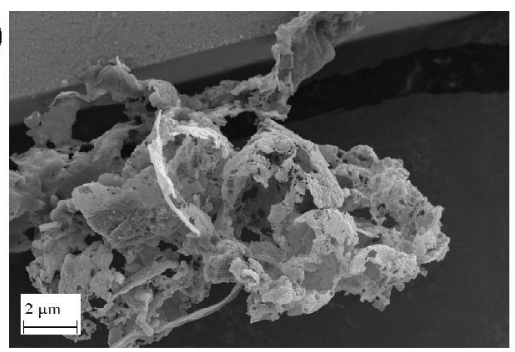

(c)

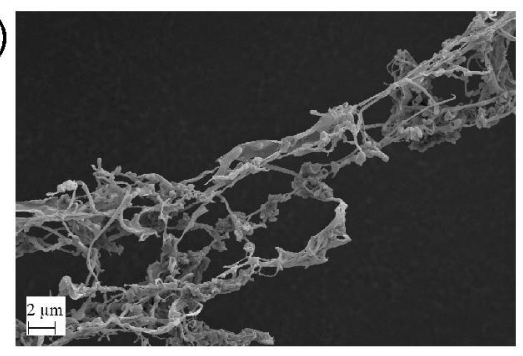

(d)

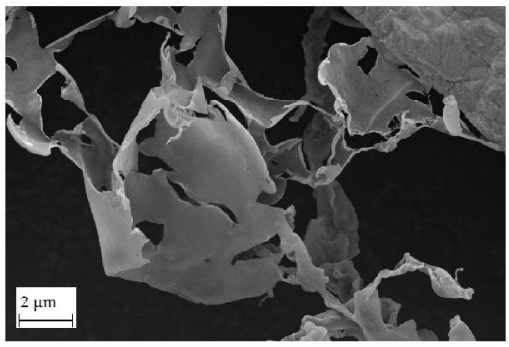

(e)

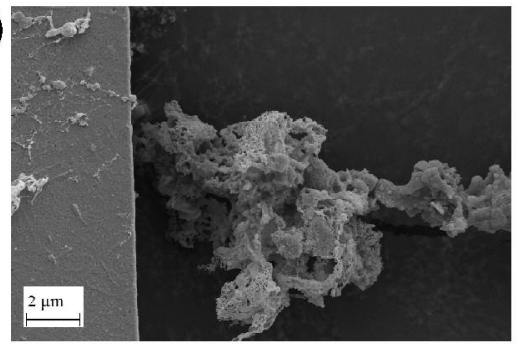

Figure S2. SEM image of compounds prior to heating. (a) Compound 1. (b) Compound 2. (c) Compound 3. (d) Compound 4. (e) Control compound 5.

(a)

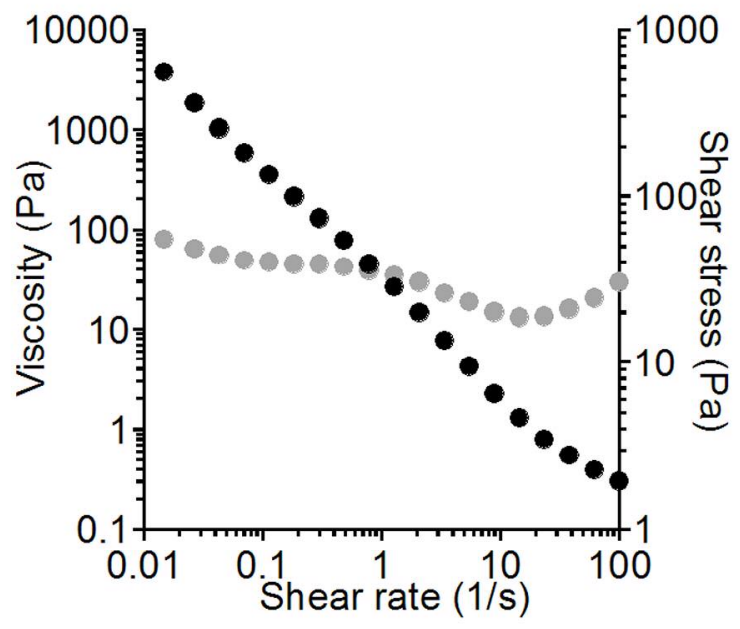

(b)

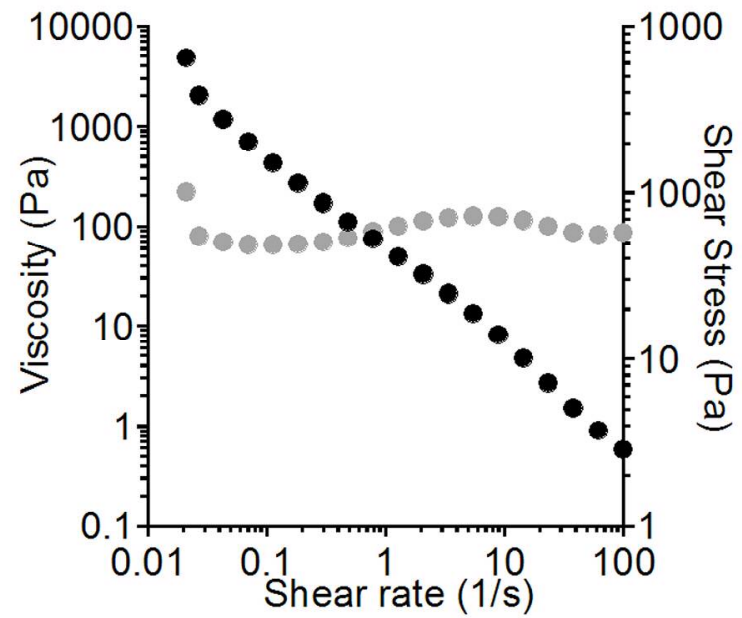

Figure S3. Shear thinning behavior of (a) compound 2 and (b) compound 3.

\section{Reference}

(1) Zych, A.J.; Iverson, B.L. J. Am. Chem. Soc. 2000, 122, 8898-8909. 